Spiral Structure of Chromosomes in Osmunda

THE accompanying photographs (Fig. 1) show the kind of results which are being obtained by application of Sax's method ${ }^{1}$ for spiral structure to the meiotic chromosomes of the Royal Fern (Osmunda regalis). Both photographs represent gemini at the metaphase of the first division of the spore mother cells ; Fig. $1(a)$ is a photomicrograph of a pair of chromosomes united by a single sub-terminal chiasma, Fig. $\mathbf{l}(b)$ is a photomicrograph of a pair joined by two chiasmata, one at each end. Both show major spirals of about five coils per chromosome, the two chromatids in each chromosome being in close contact, except at the chiasmata, and occupying the same spiral path.

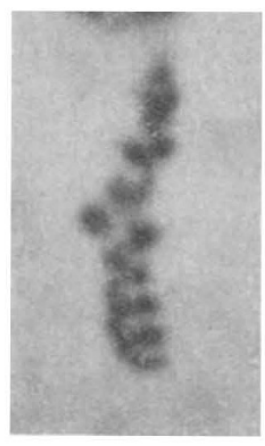

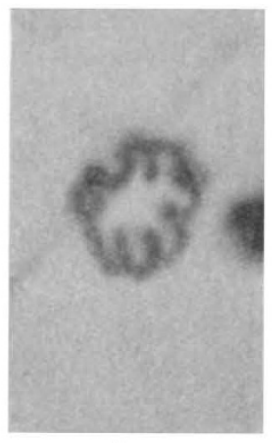

Fig. 1. Photomicrographs of single gemini at the first meiotic metaphase in $O$. regalis, from smears stained in gentian violet. $\times \mathbf{4 0 0 0}$.

Spiral structure promises to become a cytological phenomenon of very considerable theoretical importance, for it may be a clue to a structural explanation of salient features of chromosome behaviour. For this reason it is particularly desirable that the initial facts should be established beyond dispute, and one of the most essential of these is to ascertain the universality or otherwise of the phenomenon. With few exceptions, the published figures refer to monocotyledonous plants belonging to a relatively small number of families, namely, Liliaceæ in Lilium $^{2,3}$, Fritillaria $^{4}$, Trillium ${ }^{5,6}$, Tulipa ${ }^{7}$, etc. ; Comellinaceæ in Tradescantia ${ }^{8,9}$, Rhœo $^{1}$, Zebrina ${ }^{10}$; Alismaceæ in Sagittaria 11 Among dicotyledons, details are available for Lathyrus ${ }^{12}$ and Vicia ${ }^{1}$ with unfigured verbal reference to a few other genera. Similar verbal reference without figures has been made for one gymnosperm, namely, Cryptomeria japonica ${ }^{10}$. A significant widening of the field is thus effected by the addition of Osmunda to the list, a plant classed as a relatively primitive vascular cryptogam and with a fossil record extending back to the Carboniferous period.

Fuller details for the Osmundaceæ will be given elsewhere.

Botany Department,

I. MANTON.

University of Manchester. Nov. 21.

1. Sax, J. Arnold Arboretum (1935)

2 Kato and Iwata, Mem. Coll. Sci., B, Kyoto Imp. Univ. (1935).

Iwata, ibid. (1935).

Darlington, Proc. Roy. Soc., B, (1935).

Huskins and Smith, Ann. Bot., (1935).

Matsuura, Cytologia, etc. (1935).

Upcott, NATURE, 135, 957 (1935).

${ }^{8}$ Fujii, Report Jap. Assoc. Advan. Sci., (1926). Kuwada and Sugimoto, Bot. Mag., Tokyo (1926). Kuwada, Bot. Mag., Tokyo (1926 and later). Sakamura, Bot. Mag., Tokyo (1927), etc.

- Nebel, $Z$. Zellforsch., (1932), and others.

10 Shinke, Mem. Coll. Sci. Kyoto Imp. Univ., B (1930).

11 ibid., (1934).

12 Maeda, Bot. Mag., Tokyo (1928).

\section{Feeding Habits of Stick Insects}

THE observations ${ }^{1}$ from the Notre Dame Training College, Glasgow, on the eating of dead cellulose by Carausius, are very interesting in view of our experience at Strand School, where we have kept stick insects for upwards of twenty-five years, incidentally, without having detected a male.

Ours are fed on green privet, but on occasion, we have tried them with the golden variety, and, while some would eat it quite readily, others refused to touch it, though we never found any difficulty in starting them on it straight from the egg.

We have records of the insects devouring their sloughs, and on one occasion. I saw one eating the front legs and antennæ of another insect which had assumed the akinetic condition in which, as is well known, they lose all sense of feeling. This seems worth recording, as it illustrates how a new habit might be formed through the miscarriage, as it were, of a protective device.

Strand School,

London, S.W.2.

Nov. 21.

${ }^{2}$ Carmela Hayes, Nature, 188, 886 (1936).

\section{Genetics in the Universities}

THE essence of a satisfactory course in cytology and genetics is that it should be treated as a branch of biology, rather than as something taken from botany added to something taken from zoology. In a word, the course should be given by a cytologist and geneticist. A composite course shared between a botanist and a zoologist, however sympathetic their co-operation, would be likely to reveal incomplete fusion and to result in overlapping, although admittedly it would be vastly preferable to the two separate and entirely uncorrelated courses often given at present.

The subject matter of cytology and genetics is sufficiently homogeneous yet distinct from other branches of biology (and of sufficient importance) to warrant treatment by a specialist. In a university like that of London, in which I happen to be specially interested, it is unreasonable to expect that every constituent college should possess such a specialist on its botanical or zoological staff, and the obvious solution would appear to be for the University to organize courses dealing with aspects of cytology and genetics from among its teachers as a whole, rather than to leave it to each individual college to provide such courses.

The University of London is in process of acquiring a new central building and now would seem to be an appropriate moment to consider whether the centralization of courses on special aspects of biology should not be attempted, not only on behalf of overworked teachers who are compelled to cope with aspects of their subject on which they cannot speak with authority, but also for the sake of degree students who waste more time in hearing the same subject-matter reduplicated in different courses of college lectures than they would do in attending a coherent course at a common centre.

\section{W. NeILSON JoNES.}

Bedford College for Women, University of London. 